Pesq. Vet. Bras. 37(3):287-290, março 2017 DOI: $10.1590 / \mathrm{S} 0100-736 \mathrm{X} 2017000300013$

\title{
Effect of a synthetic analogue of the feline facial pheromone on salivary cortisol levels in the domestic cat ${ }^{1}$
}

\author{
Bianca P.L. da Silva² ${ }^{2}$ Fabiana B. Knackfuss ${ }^{3}$, Norma Labarthe ${ }^{2}$ and Flavya \\ Mendes-de-Almeida ${ }^{2 *}$
}

\begin{abstract}
Silva B.P.L., Knackfuss F.B., Labarthe N. \& Mendes-de-Almeida F. 2017. Effect of a synthetic analogue of the feline facial pheromone on salivary cortisol levels in the domestic cat. Pesquisa Veterinária Brasileira 37(3):287-290. Programa de Pós-Graduação em Medicina Veterinária, Universidade Federal Fluminense, Rua Vital Brazil Filho 64, Niterói, RJ 24230-340, Brazil. E-mail: flavyama@id.uff.br

This study aimed to evaluate the ability of a saliva collection device (Salivette ${ }^{\circledR}$ ) to measure cortisol levels in saliva samples of domestic cats and to assess the effect of a synthetic analogue of the feline facial pheromone fraction F3 (Feliway ${ }^{\circledR)}$ on cortisol levels. A total of 28 domestic cats from a private high-quality sanctuary were sampled before exposure to the facial pheromone and after 35 days of exposure. Two pheromone devices were placed in the area where the animals ate to guarantee the exposure of all cats. The collecting device yielded a sufficient volume of saliva $(\geq 0.20 \mathrm{~mL})$ to allow cortisol measurement. Cortisol measurements ranged from $0.02 \mathrm{~g} / \mathrm{dL}$ to $0.16 \mu \mathrm{g} / \mathrm{dL}$, with a difference between before $(42.1 \%)$ and after $(62.6 \%)$ exposure to the pheromone $(F=3.2351 ; p \leq 0.0002)$. No difference in cortisol levels was observed between before $(\bar{x}=0.078 \mu \mathrm{g} / \mathrm{dL})$ and after $(\bar{x}=0.066 \mu \mathrm{g} / \mathrm{dL})$ $(\mathrm{t}=1.79 ; p=0.08)$ exposure. However, salivary cortisol levels decreased in $75 \%(21 / 28)$ of the cats after exposure $\left(x^{2}=12.07 ; p=0.0005\right)$, suggesting that the animals have different susceptibilities to the pheromone or that they spent different lengths of time in the area where the pheromone devices were installed.
\end{abstract}

INDEX TERMS: Cortisol, cat., stress, welfare enhancement, behavior, salivette, pheromone.

RESUMO.- [Efeito do análogo sintético do feromônio facial felino sobre o nível de cortisol salivar de gatos domésticos.] 0 presente estudo avaliou o uso de um dispositivo de coleta salivar (Salivette ${ }^{\circledR}$ ) para mensurar o cortisol salivar de gatos domésticos e avaliar o efeito do análogo sintético do feromônio facial felino - fração F3 (Feliway ${ }^{\circledR}$ ) sobre seus níveis de cortisol. Um total de 28 gatos domésticos mantidos em gatil particular tiveram amostras de saliva coletadas antes da exposição ao feromônio facial felino e após 35 dias de exposição. Dois difusores de feromônio foram instalados na área onde os animais se alimentavam, a fim de garantir que todos os gatos fossem expostos. Os dispositivos de coleta salivar permitiram a coleta de vo-

\footnotetext{
${ }^{1}$ Received on March 23, 2016.

Accepedted for publication on August 19, 2016.

${ }^{2}$ Faculdade de Veterinária, Universidade Federal Fluminense (UFF), Rua Vital Brazil Filho 64, Niterói, RJ 24230-340, Brazil. *Corresponding author: flavyama@id.uff.br

${ }^{3}$ Universidade do Grande Rio, Rua Prof. José Herdy 1160, Duque de Caxias, RJ 25071-202, Brazil.
}

lume salivar suficiente $(\geq 0,20 \mathrm{~mL})$ para a mensuração do cortisol. Os níveis de cortisol salivar variaram de $0,02 \mathrm{~g} /$ $\mathrm{dL}$ a $0,16 \mathrm{ug} / \mathrm{dL}$, com coeficiente de variação de $42,1 \%$ antes e de $62,6 \%$ após à exposição ao feromônio $(F=3.2351$; $p \leq 0.0002)$. Não foi verificada diferença entre os níveis de cortisol salivar nas amostras obtidas antes $(\bar{x}=0,078 \mu \mathrm{g} /$ $\mathrm{dL})$ e após $(\bar{x}=0,066 \mu \mathrm{g} / \mathrm{dL})(\mathrm{t}=1,79 ; p=0,08)$ à exposição. Entretanto, os níveis de cortisol salivar diminuíram em $75 \%(21 / 28)$ dos gatos expostos ao feromônio $\left(x^{2}=12,07\right.$; $p=0,0005$ ), sugerindo que os animais apresentam susceptibilidade diferente ao feromônio facial sintético ou que passaram períodos de tempo distintos na área onde os difusores foram instalados.

TERMOS DE INDEXAÇÃO: Cortisol, felino, estresse, enriquecimento ambiental, comportamento, salivette, feromônio.

\section{INTRODUCTION}

To identify stress in domestic cats, the natural behavior of these animals and the influence of domestication on this behavior must be understood (Kessler et al. 1997). Plasma 
or salivary cortisol has been used as a biomarker of stress (Cooper et al. 1989, Beerda et al. 1996, Whitten 1998, Dreschel \& Granger 2005, Hellhammer et al. 2009, Montanha et al. 2009). It has been shown that salivary and plasma levels of cortisol are correlated (Beerda et al. 1996) and the measure of the basal cortisol levels in domestic cats using saliva samples was previously studied and validated (Siegford et al. 2003). Therefore, because it is non-invasive and, consequently, less stressful for the animal, the collection of saliva represents an interesting method of measuring cortisol (Hellhammer et al. 2009).

Cats leave odoriferous markers in the environment by rubbing, scratching and urinating. All of these natural behaviors represent ways of transmitting information. Cats rub their heads against objects when they feel comfortable in and familiar with an environment. When cats enter into a marked environment, they recognize it as a safe or as an unfriendly territory. If the cat marked the territory as safe, then the animal will be comfortable. In contrast, if it was marked by others, the animal perceives it as unsafe and becomes stressed (Carlstead et al. 1993, Feldman 1994). There are also markers that cats use for generic signaling for safety or danger in the environment (Mills \& Mills 2001).

Stressful conditions are especially unfavorable to feline immunodeficiency virus (FIV)-positive cats because the virus can aggravate or induce immunosuppression by physiological elevation of cortisol levels (Paillot et al. 2005). Cats perceive environments where the synthetic analogue of the feline facial pheromone fraction F3 has been used as safe as these environments appear to have been previously marked as friendly. Cats trust such environments, resulting in decreased stress (Mills \& Mills 2001).

Accordingly, this study aimed to evaluate the ability of a saliva collection device (Salivette ${ }^{\circledR}$ ) to measure salivary cortisol levels and to evaluate the effects of a synthetic analogue of the feline facial pheromone fraction F3 on the levels of salivary cortisol in FIV-positive domestic cats.

\section{MATERIALS AND METHODS}

Ethics statement. This project was approved by the ethics commission on animal use (ceua) of the universidade federal fluminense (UFF) under registration \#248.

Fifty sociable neutered domestic cats of a variety of ages, sexes and breeds that were FIV-positive and feline leukemia virus (FeLV)-negative, as determined by an immunoenzymatic kit (SNAP Combo ${ }^{\circledR}$ Lab. IDEXX, Maine, USA), and had been housed for at least six months in the FIV-positive and FeLV-negative facility of a private cat sanctuary, Sociedade Brasileira de Proteção Animal e do Meio Ambiente SOS Animal-Felinos, were examined. Any animal showing clinical signs associated with an advanced stage of FIV, such as respiratory disease or stomatitis, was excluded; therefore, 30 animals were included in the study.

FIV-positive and FeLV-negative cats were kept isolated from FIV-negative or FeLV-positive cats in a facility area of about $450 \mathrm{~m}^{2}$, with an internal area of $40.60 \mathrm{~m}^{2}$, a balcony area of $39.05 \mathrm{~m}^{2}$ and an enclosed area of $368.06 \mathrm{~m}^{2}$ covered with sand. The housing maximum density was 0.11 cats $/ \mathrm{m}^{2}$. All animal handling was performed by two veterinarians, with the assistance of a shelter staff member at the animal housing facility where they were kept.

Previous history of all the animals (age, gender, weight, color, distinguishing marks, time of detection of FIV antibodies) was provided by the sanctuary, and as they were microchipped their identification was readily done by the use of a microchip reader immediately before inspection for clinical signs of disease. The inspection included mucosal inspection, temperament and palpation of the lymph nodes and abdomen.

Saliva was collected from the cats immediately after the inspection as follows: the veterinarian restrained the cat while the other introduced an adsorbent swab (Salivette ${ }^{\circledR}$, Sarstedt, Germany) into the lateral commissure of the mouth of each animal for a collection period of 2 to 4 minutes. Both veterinarians were always the same and the procedure was standard. After saliva was sampled on day 0 , two diffusers of the synthetic analogue of the feline facial pheromone fraction F3 (Feliway ${ }^{\circledR}$, Ceva Saúde Animal Ltda, SP, Brasil) were installed in the internal area at a height of $2.5 \mathrm{~m}$ and were operated for 35 days; saliva was again sampled on day 35. Food and water were provided in the internal area, where the cats spent most of the time and could therefore be exposed to the feline facial pheromone fraction F3 (Feliway ${ }^{\circledR}$ ).

Once impregnated with saliva, the swabs were immediately packed into the appropriate tubes and centrifuged at $100 \mathrm{xg}$ for 5 min. Immediately after centrifugation, the tubes were refrigerated $\left(4^{\circ} \mathrm{C}\right)$ for no more than 6 hours before freezing $\left(-20^{\circ} \mathrm{C}\right)$. Samples were kept at $-20^{\circ} \mathrm{C}$ until analysis. The cortisol levels in all saliva samples were simultaneously measured by an immunoassay (Salivary Cortisol ELISA Kit - Salimetrics ${ }^{\circledR}$, California, USA) at the Genese Institute of Scientific Analysis (IgAc), Sao Paulo, SP.

Statistics. All data were kept in a spreadsheet using MS-Excel 2003 software, and for the statistical analysis, BioEstat 5.0 was used (Ayres et al. 2007). Salivary cortisol values from the two different samplings were compared by analysis of variance with repeated measurements (ANOVA) and by descriptive analysis, including medians, means, standard deviations and coefficients of variation. To evaluate the difference between the mean salivary cortisol values obtained in the first and second analysis, Student's T-test was used. A Chi-square test was used to evaluate the significance of the number of cats with decreased salivary cortisol levels on day 35 . The significance level adopted was $p<0.05$.

\section{RESULTS}

On day 0 , all cats had normal-colored mucosa; none had abnormal findings upon abdominal palpation, and 10 of the cats had slightly enlarged lymph nodes that were not sufficiently enlarged to warrant exclusion from the study.

On day 0 , the 30 cats were sampled, and on day 35, two of the cats had been transferred and were therefore were excluded from the study. Most of the 28 cats that were sampled and completed the study weighed 2 to $4 \mathrm{~kg}$; the largest age group consisted of animals aged 2 to 6 years, and $61 \%$ were female (Table 1). The volume of saliva obtained from each cat ranged from 0.2 to $1 \mathrm{~mL}$, which was sufficient to measure cortisol in all samples.

The overall range of salivary cortisol was from $0.02 \mathrm{~g} /$ $\mathrm{dL}$ to $0.16 \mu \mathrm{g} / \mathrm{dL}$ (Fig.1), with a difference in variation before $(42.1 \%)$ and after $(62.6 \%)$ exposure to the pheromone $(F=3.2351 ; p \leq 0.0002)$.

Although the salivary cortisol levels of most of the cats decreased after pheromone use, no difference could be observed when day $0(\bar{x}=0.078 \mu \mathrm{g} / \mathrm{dL})$ was compared with day $35(\bar{x}=0.066 \mu \mathrm{g} / \mathrm{dL})(\mathrm{t}=1.79 ; p=0.08)$. However, the salivary cortisol levels decreased in $75 \%(21 / 28)$ of the cats 
Table 1. Description of the FIV+/FeLV- domestic cats included in the study to evaluate salivary cortisol levels before and after 35 days of exposure to a synthetic analogue of the feline facial pheromone fraction F3*

\begin{tabular}{lcccccccc}
\hline & \multicolumn{3}{c}{ Age (\%) } & \multicolumn{5}{c}{ Weight - $\mathrm{kg}(\%)$} \\
\hline Gender & $\mathrm{N}$ & 6 mo-2 y & $2-6 \mathrm{y}$ & $>6 \mathrm{y}$ & $2-3$ & $>3-4$ & $>4-5$ & $>5-6$ \\
\hline Female & 17 & 35.3 & 47.1 & 17.6 & 64.7 & 29.5 & 5.8 & 0 \\
Male & 11 & 27.3 & 72.7 & 0 & 9.1 & 54.5 & 18.2 & 18.2 \\
Total & 28 & 32.1 & 57.1 & 10.8 & 42.8 & 39.3 & 10.7 & 7.2
\end{tabular}

FIV = Feline immunodeficiency virus; FeLV = Feline leukemia virus; $\mathrm{N}=$ Number of animals; ${ }^{*}$ Feliway ${ }^{\circledR}=$ Ceva Saúde Animal Ltda, SP, Brasil.

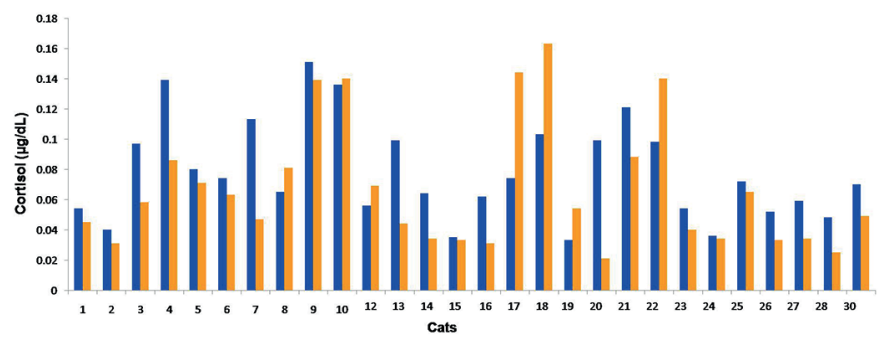

Fig.1. Levels of salivary cortisol in domestic cats before (blue) and after 35 days of exposure to the synthetic analogue of feline facial pheromone fraction F3 (Feliway ${ }^{\circledR}$ ) (orange).

on day $35\left(x^{2}=12.07 ; p=0.0005\right)$, with greater variability within the group confirmed by the coefficient of variation (62.6\%) (Fig.1). Males responded better to the pheromone than females $\left(x^{2}=4.04 ; p=0.02\right)$, once the 7 non-responders were females.

All 28 cats permitted sampling, although some of them were resistant to the procedure. On day 0 , five cats struggled, and on day 35, eight cats struggled. Among these, only three resisted on both of the sampling days, and of the other five cats, only two showed increased cortisol levels on day 35 (Fig.1). The efficacy of saliva sampling using the Salivette ${ }^{\circledR}$ device to measure domestic cat cortisol was demonstrated once it obtained enough material to allow accurate measurements.

\section{DISCUSSION}

Infection with the feline immunodeficiency virus predisposes cats to opportunistic infections (Pedersen et al. 1987, 0`Neil et al. 1995, Paillot et al. 2005, Troth et al. 2008, Tompkins \& Tompkins 2008). However, none of the animals included had severe clinical signs, suggesting that the hygienic conditions of the shelter and the care provided to the animals were appropriate.

The range of cortisol levels was narrower before the use of the facial pheromone fraction F3 as confirmed by the difference in the coefficients of variation, although the levels at both measurements were similar to reference levels for the species (Siegford et al. 2003). Even though cortisol levels were within the expected range, levels of most cats decreased after pheromone use, although with great variability, suggesting that the synthetic pheromone affected the animals to different degrees but can nonetheless be used to control feline stress. Interestingly, all 7 animals that did not respond to the pheromone were females, suggesting that females are less sensitive to the effects of the pheromone than males or that they spent less time indoors, where the diffusers were placed.

Even when the number of cats resisting the sampling procedure was higher (second sampling), most samples had lower cortisol levels, suggesting that handling stress was insufficient to preclude the beneficial effect of the pheromone.

\section{CONCLUSIONS}

Since $75 \%$ of the cats had lower levels of salivary cortisol following exposure to the synthetic facial pheromone fraction F3, the use of this pheromone appears to help control feline stress.

Moreover, the salivary collection system was efficient, and cortisol levels in the saliva could be effectively measured.

The cats that struggled during the saliva collection procedure did not have higher levels of salivary cortisol, suggesting that stress associated with handling did not affect salivary cortisol concentrations.

Acknowledgements.- The authors acknowledge Programa de Fomento à Pesquisa - FOPESQ/UFF for providing financial support; CNPq, for the scholarship; Dr. Marcele Elisa Azeredo Carlota and Mrs. Ester Freitas Fernandes, for making this work possible; Sociedade Brasileira de Proteção Animal e do Meio Ambiente SOS Animal-Felinos, for technical support; and Mrs. Ruth Albuquerque, for her extreme dedication to the abandoned cats and for the maintenance of the feline sanctuary.

Conflict of interest statement.- The authors have no competing interests.

\section{REFERENCES}

Ayres M., Ayres Jr M., Ayres D.L. \& Dos Santos A. de A.S. 2007. BioStat aplicações estatísticas nas áreas das Ciências Biomédicas. 5a ed. Mamirauá, Belém. 324p.

Beerda B., Schilder M.B.H \& Mol J.A. 1996. The use of salivary cortisol, urinary cortisol, and catecholamine measurements for a noninvasive assessment of stress response in dogs. Hormo. Behav.30:272-279.

Carlstead K., Brown J.L. \& Strawn W. 1993. Behavioral and physiological correlates of stress in laboratory cats. Appl. Anim. Behav. Sci.38:143158.

Cooper T.R., Trunkfield H.R., Zanella A.J. \& Booth W.D. 1989. An enzymelinked immunoabsorbent assay for cortisol in the saliva of man and domestic farm animals. J. Endocrinol. 123:13-16.

Dreschel N.A. \& Granger D.A. 2005. Bio behavioral reactivity to stress in thunderstorm-anxious canines and their caregivers. Appl. Anim. Behav. Sci.95:153-168.

Feldman H.N. 1994. Methods of scent marking in the domestic cat. Can. J. Zool. 72:1093-1099.

Hellhammer D.H., Wust S. \& Kudielka M.B. 2009. Salivary cortisol as a biomarker in stress research. Psychoneuroendocrinology 34:163-171.

Mills D.S. \& Mills C.B. 2001. Evaluation of a novel method for delivering a synthetic analogue of feline facial pheromone to control urine spraying by cats. Vet. Rec.149:197-199.

Montanha J.C., Silva S.L. \& Boere V. 2009. Comparison of salivary cortisol concentration in Jaguars kept in captivity with differences in exposure to the public. Ciência Rural 39:1745-1751.

O Neil L.L., Burkhard M.J., Diehl L.J. \& Hoover E.A. 1995. Vertical transmission of feline immunodeficiency virus. AIDS Res. Hum. Retroviruses 10:267-278.

Paillot R., Richard S., Bloas F., Piras F., Poulet H., Brunet S., Andreoni C. \& 
Juillard V. 2005. Toward a detailed characterization of feline immunodeficiency virus-specific $\mathrm{T}$ cell immune responses and mediated immune disorders. Vet. Immunol. Immunopathol.106:1-14.

Pedersen N.C., Ho E.W., Brown M.L. \& Yamamoto J.K. 1987. Isolation of a Tymphotropic virus from domestic cats with a immunodeficiency-like syndrome. Science 235:790-793.

Siegford J.M., Walshaw S.O., Brunner P. \& Zanella A.J. 2003.Validation of a temperament test for domestic cats. Anthrozoos 16:332-351.
Tompkins M.B. \& Tompkins W.A. 2008. Lentivirus-induced immune dysregulation. Vet. Immunol. Immunopathol. 123:45-55.

Troth S.P., Dean A.D. \& Hoover E.A. 2008. In vivo CXCR4 expression, lymphoid cell phenotype, and feline immunodeficiency virus infection. Vet. Immunol. Immunopathol. 123:97-105.

Whitten P.L., Brockman D.K. \& Stavisky R.C. 1998. Recent advances in noninvasive techniques to monitor hormone-behavior interactions. Yearb. Phys. Anthropol. 41:1-23. 